\title{
Strategic After-Sales Service Analysis Based on Balanced Scorecard in Present-Day Global Economic Environment
}

\author{
Sergey Krylov ${ }^{1, *}$ \\ ${ }^{1}$ Ural Federal University, Academic Department of Accounting, Analysis and Audit, Mira 19, 620002 \\ Ekaterinburg, Russian Federation
}

\begin{abstract}
.
Research background: In the present-day global economic environment ensuring the high after-sales service efficiency by decreasing the related cost raising thereby their competitiveness rate is recognized as an essential goal of the continuing (core) operations and overall performance of any organization in the long run. The goal is certain to be reached within the outcome strategic after-sales service management.

Purpose of the article: The paper considers theoretical aspects of the applied strategic after-sales service analysis (ASASSA) based on the aftersales service score of the balanced scorecard (BSC) to be applied in the research process of the strategic organization after-sales service activity aspects and its strategic after-sales service management.

Methods: The methodology of the research consists of the concept of the balanced scorecard and the concept of the applied strategic analysis developed by the author.

Findings \& Value added: ASASSA is depicted to encompass comparative assessment, variances diagnostics and indicators forecast of the after-sales service BSC score within the strategic after-sales service goals. The analysis comprises the speed of billing, payment for the goods sold, arbitrations settlement as well as analysis of due updating of the goods delivered, speed of warranty and repair excellence, and speed of poor quality's goods replacement (in case of the delivery). The author draws a conclusion is drawn that ASASSA is a new and sufficiently effective tool to research strategic aspects of the organization after-sales service activity and to form an analytical support for the modern strategic after-sales service management.
\end{abstract}

Keywords: applied strategic analysis; balanced scorecard; after-sales service; management; organization

JEL Classification: L29; M19; M41

*Corresponding author: zali6770@yandex.ru 


\section{Introduction}

In present-day economic environment every organization (enterprise, firm, and company) acquires a unique set of business processes ensuring value creation for its customers, developing and retaining its customer base within the target market segment as well as satisfying the requirements of its share holders in terms of high financial profitability. Meanwhile, there is a certain value chain model comprising three successive internal business processes: innovative process, operational process and after-sales service.

The after-sales service, as one of the internal business processes, entails servicing a customer after the goods and services have been sold and delivered to him. As a rule it is composed of the goods warranty and repair, goods updating, poor quality goods replacement, billing and payment both for the goods sold and customer credit sales.

The after-sales service is assumed as some kind of the feedback between the goods manufacturer and the customers enabling to obtain adequate information about advantages and disadvantages of the goods acquired and trends for their improvements. The after-sales service excellence paves the way to the company performance success portrayed by the customer satisfaction [1].

Ensuring the high after-sales service efficiency by decreasing the related cost raising thereby their competitiveness rate is recognized as an essential goal of the continuing (core) operations and overall performance of any organization in the long run.

The goal is certain to be reached within the outcome strategic after-sales service management. In addition, an extent of the strategic decision implementation in the field of the after-sales service management is to be assessed as well as the causes of variances (if any) are to be found, and a further situation development is to be forecast driving a development and improvement of the appropriate analytical instrumentation.

In view of the mentioned above, the author of the paper seeks to consider his applied strategic analysis (ASA) based on the balanced scorecard (BSC) to be employed in the process of the analytical support development for the strategic after-sales service management.

\section{Methods}

To enhance strategic management efficiency in difficult conditions of the present-day market economy we have developed the applied strategic analysis to improve its information-analytical support, to evolve theory, methodology and methods of the overall strategic economic activity aspects to the level of the financial analysis being an efficient research instrument of the financial aspects of the organization economic activity based on the financial indicators and described experience.

ASA, as a strategic management function, assumes an overall research of the strategic economic organization activity aspects based on the BSC $[2,3]$.

The balanced scorecard concept as an analytical instrument applied in the field of strategic management was developed by American scientists Robert Kaplan and David Norton [4] at the beginning of the 90s of the XX century, evolving both in their works [58] and those of other scientists studying economics [9-18], and was multiply tested. At present BSC is considered to be one of the essential instruments of the organization management system.

Balanced scorecard as a whole is understood as an aggregate of parameters featuring an overall organization performance in up-to-date market economy. It reflects a balance to be brought about between short-term and long-term goals, financial and non-financial indicators, basic and auxiliary parameters, as well as internal and external factors of the organization economic activity $[4,5]$. 
The scores of the balanced system are formed depending on the outlook and strategic goals of any particular organization and have individual features. They represent a balance between external accounting data for the owners (shareholders) and internal characteristics of the most significant business processes, innovations, training and growth that is the balance between the results of the organization performance and future growth. The system comprises a combination of objective quantity estimated data and subjective somewhat arbitrary parameters of future growth [6].

The main goal of the balanced scorecard is to transform a company strategy into specific tangible objectives, indicators and end up with events [13].

The balanced scorecard is founded on the cause and effect; results attain factors and their interrelation with financial data [11].

The balanced scorecard encompasses four basic interrelated elements: finance, a customer, internal business processes ones as well as training and personnel development element. The BSC scores enable to characterize comprehensively an activity of commercial, government and non-for-profit organizations, the scores being relatively few (about 25 scores in average, as a rule) [7].

It should be taken into consideration that basing on the balanced scorecard system special for any particular organization the applied strategic analysis lacks any standard methods. Hence, the ASA methods are special as well for any particular organization [2].

The goal of the applied strategic analysis implementation is to form analytical support for taking strategic management decisions.

The ASA accomplishment principle, a deduction principle presumes, firstly, an investigation of the general BSC indicators, then specific indicators. The principle defines general sequence of the ASA analysis according to the following leads: analysis of financial indicators, analysis of customer indicators, analysis of internal business-processes (process of after-sales service, operational process and innovative process) indicators, analysis of training and personnel development indicators [3].

The ASA commences from the comparative evaluation of the financial indicators and is completed by the forecast of training and personnel development.

When describing the ASA contents as a complex category of economics in his previous works the author assumed the applied strategic innovative analysis (ASIA) to be a kind of ASA presuming overall complex research of the strategic aspects of the organization innovative activity based on the innovative BSC's score [19], the applied strategic financial analysis (ASFA) implying overall complex research of the organization financial position by the BSC's financial score [20], the applied strategic customer analysis (ASCA) enabling to research overall strategic aspects of the organization sales performance by its BSC's customer score [21] as well as the applied strategic operational analysis (ASOA) allowing comprehensive research of the strategic organization operational aspects by its BSC's operational score [22]. In the present paper the author considers the following kind of ASA - an applied strategic after-sales service analysis.

\section{Results and Discussions}

The applied strategic after-sales service analysis (ASASSA), a kind of the applied strategic analysis, assumes a complex, comprehensive research of the strategic organization operational activity aspects in the field of the after-sales service of the goods manufactured basing on the after-sales service score of its balanced scorecard. It can also be taken as a facilitating function of the strategic after-sales service management.

The ASASSA subject refers to the BSC's after-sales service score indicators and the factors specifying them while the object is the strategic organization after-sales service activity aspects. 
The goal of the applied strategic after-sales service analysis is to form an analytical support of making strategic decisions in the field of the after-sales service management of the goods manufactured.

To attain the ASASSA goal it's most important objectives (analogous to the BSC ones) are to be reached, such as comparative assessment, diagnostics variances, and forecast of the balanced scorecard after-sales service score.

All the objectives of the applied strategic after-sales service analysis are closely interrelated since each subsequent objective follows from the previous one: the diagnostics of the after-sales service BSC score indicators variances is exercised by the results of their comparative assessment and the indicators forecast are derived from their diagnostics variances results.

Comparative assessment of the balanced scorecard after-sales service score implies a comparison of their real and target figures, finding absolute and comparative (in \%) variances, their qualitative evaluation that depends largely on their value (Table 1).

Table 1. Exemplary qualitative estimation of the variance characteristics of the BSC after-sales service score real and target figures.

\begin{tabular}{|c|c|}
\hline $\begin{array}{c}\text { Real figure variances values of the BSC } \\
\text { after-sales service score from the target } \\
\text { ones, } \%\end{array}$ & $\begin{array}{c}\text { Qualitative estimation of the } \\
\text { BSC after-sales service score real } \\
\text { figure from their target ones }\end{array}$ \\
\hline Up to $\pm 1 \%$ & Fairly small \\
\hline From $\pm 1 \%$ to $\pm 5 \%$ & Essential \\
\hline From $\pm 5 \%$ to $\pm 10 \%$ & Significant \\
\hline From $\pm 10 \%$ to $\pm 20 \%$ & Large \\
\hline $\pm 20 \%$ and higher & Very large \\
\hline
\end{tabular}

The diagnostics of the balanced scorecard after-sales service score indicators variance is based on the cause and effect links combining the BSC scores, the after-sales service score included, into the balanced complex of the outcome (general) indicators and their specifying factors (results attaining factors). In the course of diagnosing the balanced scorecard after-sales service score indicators variances found are results attaining factors, which impact mostly the general or outcome indicators of the BSC after-sales service score, and determined is its value by the relevant factoring analysis. The conclusions are drawn by the results obtained. It should be noted that the outcome indicators of the more specific BSC elements (innovative score, operational and personnel training and development scores) could be considered as the factors determining the factoring indicators variances of the more general after-sales service score.

The forecast of the BSC after-sales service score indicators values is of the purposeful nature and implies either primordial establishment or adjustment of the target BSC aftersales service score indicators values (in case of the objective conditions) and determination of the specific methods of their attainment or the development of the events aimed at the elimination of the variances emerged between the outcome and target values of the BSC after-sales service score indicators in the future. In addition, the forecast commences with the general (outcome) indicators, the factoring ones being derived from them.

The aspects of the ASASSA as a kind of ASA refer to a strategic aspect proper, as well as tactical aspect and operative aspect. Within the scope of the strategic aspect of the applied strategic after-sales service analysis evaluated, diagnosed and forecast are final BSC after-sales service score indicators for the time-period of the developed strategy functioning, i.e., their strategic values. Within the frame of the tactical aspect of the applied strategic after-sales service analysis evaluated, diagnosed and forecast are interim BSC after-sales service score indicators by the each year end, i.e., their tactical values. Within the course of the operative aspect applied strategic after-sales service analysis evaluated, 
diagnosed and forecast are interim BSC after-sales service score indicators by the end of each month, i.e., their operative values. It should be noted, that all the ASASSA aspects mentioned are interrelated and agreed: the results of the operative BSC after-sales service score indicators values analysis makes an impact on their tactical values and the results of the tactical values analysis - on the strategic ones.

The applied strategic after-sales service analysis methodology instruments comprise an aggregate of techniques (ways, methods) to facilitate handling the essential problems of the analysis exercised and, respectively, its goal reached. The basic techniques of the ASASSA include methods of absolute, relative and average values, comparison, grouping, graphic and table methods, correlation-regression analysis, factoring analysis, cluster analysis, and expert evaluation methods.

The ASASSA information base is the BSC after-sales service score (Table 2), the formation comprising a number of steps: definition of the strategic after-sales service goals, construction of the strategic after-sales service map, selection of the after-sales service indicators, definition of the after-sales service indicators values, development of the strategic after-sales service events.

Table 2. BSC after-sales service score of the organization development.

\begin{tabular}{|c|c|c|c|c|}
\hline $\begin{array}{c}\text { Key issue of the BSC } \\
\text { after-sales service score }\end{array}$ & $\begin{array}{c}\text { Strategic goals of } \\
\text { the after-sales } \\
\text { service process }\end{array}$ & $\begin{array}{c}\text { After-sales } \\
\text { service } \\
\text { process } \\
\text { indicator }\end{array}$ & $\begin{array}{c}\text { Target } \\
\text { value }\end{array}$ & $\begin{array}{c}\text { Strategic } \\
\text { after-sales } \\
\text { service } \\
\text { event }\end{array}$ \\
\hline $\begin{array}{c}\text { What goals concerning } \\
\text { after-sales service are to be } \\
\text { set to attain the following } \\
\text { customer and financial } \\
\text { goals, respectively? }\end{array}$ & & & & \\
\cline { 2 - 5 } & & & & \\
\cline { 2 - 5 } & & & & \\
\hline
\end{tabular}

The applied strategic after-sales service analysis as a kind of the applied strategic analysis is carried out in compliance with the principle of deduction encompassing research firstly, general indicators of the BSC after-sales service score element then specific ones.

The basic components of the ASASSA are the following:

1. Analysis of speed of billing, payment for the goods sold and arbitrations settlement.

2. Analysis of due delivered goods updating.

3. Analysis of speed of warranty and repair excellence.

4. Analysis of speed of poor quality's goods replacement (in case of the delivery).

The process of the ASASSA analysis exercise can be presented by means of considering its main objectives, i.e. comparative assesment, diagnostics of the variance and the forecast of the BSC after-sales service score (Table 3).

Examples of the outcome and factoring indicators analyzed per every complex ASASSA score are provided in Table 4.

The conceptual base of the applied strategic after-sales service analysis, as a new instrument to research comprehensively the strategic aspects of the organization after-sales service activity through the balanced scorecard after-sales service score, discussed above, define some general contours of the ASASSA as new research and performance leads, providing a theoretical basis for its further development in terms of its practical application aspect. 
Table 3. Matrix of the ASASSA scores.

\begin{tabular}{|c|c|c|c|}
\hline \multirow[b]{2}{*}{$\begin{array}{c}\text { Basic ASASSA } \\
\text { scores (i) }\end{array}$} & \multicolumn{3}{|c|}{ Major ASASSA objectives (j) } \\
\hline & $\begin{array}{c}\text { Comparative } \\
\text { assessment of the } \\
\text { BSC after-sales } \\
\text { service score } \\
\text { indicator values (1) }\end{array}$ & $\begin{array}{l}\text { Diagnostics of the } \\
\text { BSC after-sales } \\
\text { service score } \\
\text { indicator values } \\
\text { variances (2) }\end{array}$ & $\begin{array}{l}\text { Forecast of the BSC } \\
\text { after-sales service } \\
\text { score indicator } \\
\text { values (3) }\end{array}$ \\
\hline $\begin{array}{l}\text { Analysis of speed of } \\
\text { billing, payment for } \\
\text { the goods sold and } \\
\text { arbitrations } \\
\text { settlement (1) }\end{array}$ & $\begin{array}{c}\text { Comparative } \\
\text { assessment of the } \\
\text { values of the speed of } \\
\text { billing, payment for } \\
\text { the goods sold and } \\
\text { arbitrations settlement } \\
\text { indicator }\end{array}$ & $\begin{array}{l}\text { Diagnostics of the } \\
\text { speed of billing, } \\
\text { payment for the goods } \\
\text { sold and arbitrations } \\
\text { settlement indicator } \\
\text { values variances }\end{array}$ & $\begin{array}{l}\text { Forecast of the speed } \\
\text { of billing, payment } \\
\text { for the goods sold } \\
\text { and arbitrations } \\
\text { settlement indicator } \\
\text { values }\end{array}$ \\
\hline $\begin{array}{l}\text { Analysis of due } \\
\text { delivered goods } \\
\text { updating (2) }\end{array}$ & $\begin{array}{l}\text { Comparative } \\
\text { assessment of the } \\
\text { values of the due } \\
\text { delivered goods } \\
\text { updating indicator }\end{array}$ & $\begin{array}{l}\text { Diagnostics of the due } \\
\text { delivered goods } \\
\text { updating indicator } \\
\text { values variances }\end{array}$ & $\begin{array}{l}\text { Forecast of the due } \\
\text { delivered goods } \\
\text { updating indicator } \\
\text { values }\end{array}$ \\
\hline $\begin{array}{l}\text { Analysis of speed of } \\
\text { warranty and repair } \\
\text { excellence (3) }\end{array}$ & $\begin{array}{l}\text { Comparative } \\
\text { assessment of the } \\
\text { values of the speed of } \\
\text { warranty and repair } \\
\text { excellence indicator }\end{array}$ & $\begin{array}{l}\text { Diagnostics of the } \\
\text { speed of warranty and } \\
\text { repair excellence } \\
\text { indicator values } \\
\text { variances }\end{array}$ & $\begin{array}{l}\text { Forecast of the speed } \\
\text { of warranty and } \\
\text { repair excellence } \\
\text { indicator values }\end{array}$ \\
\hline $\begin{array}{l}\text { Analysis of speed of } \\
\text { poor quality's goods } \\
\text { replacement (if } \\
\text { delivered) (4) }\end{array}$ & $\begin{array}{l}\text { Comparative } \\
\text { assessment of the } \\
\text { values of the speed of } \\
\text { poor quality's goods } \\
\text { replacement (if } \\
\text { delivered) indicator }\end{array}$ & $\begin{array}{l}\text { Diagnostics of the } \\
\text { speed of poor } \\
\text { quality's goods } \\
\text { replacement (if } \\
\text { delivered) indicator } \\
\text { values variances }\end{array}$ & $\begin{array}{l}\text { Forecast of the speed } \\
\text { of poor quality's } \\
\text { goods replacement } \\
\text { (if delivered) } \\
\text { indicator values }\end{array}$ \\
\hline
\end{tabular}

Table 4. Examples of the analyzed outcome and factoring indicators per every complex ASASSA score.

\begin{tabular}{|c|c|c|}
\hline \multirow{2}{*}{ Basic ASASSA scores } & \multicolumn{2}{|c|}{ Indicators analyzed } \\
\hline & Outcome & Factoring \\
\hline $\begin{array}{l}\text { 1. Analysis of speed of } \\
\text { billing, payment for the } \\
\text { goods sold and } \\
\text { arbitrations settlement }\end{array}$ & $\begin{array}{l}\text { Average speed of billing. } \\
\text { Average time-period of payment } \\
\text { for the goods sold. } \\
\text { Average time-period of } \\
\text { arbitrations settlement. }\end{array}$ & $\begin{array}{l}\text { Speed of billing to certain } \\
\text { customers. } \\
\text { Time-period of payment for the } \\
\text { goods sold by certain customers. } \\
\text { Time-period of arbitrations } \\
\text { settlement with certain } \\
\text { customers. }\end{array}$ \\
\hline $\begin{array}{l}\text { 2. Analysis of due } \\
\text { delivered goods } \\
\text { updating }\end{array}$ & $\begin{array}{l}\text { Average time-period of delivered } \\
\text { goods updating. }\end{array}$ & $\begin{array}{l}\text { Time-period of goods updating } \\
\text { delivered to certain customers. } \\
\text { Cost for delivered goods } \\
\text { updating. }\end{array}$ \\
\hline $\begin{array}{l}\text { 3. Analysis of speed of } \\
\text { warranty and repair } \\
\text { excellence }\end{array}$ & $\begin{array}{l}\text { Absolute and comparative of } \\
\text { time cycle changes. } \\
\text { A share of repeat claims for } \\
\text { repair and warranty within } \\
\text { overall claims. } \\
\text { A share of repeat claims for } \\
\text { warranty satisfied at the first }\end{array}$ & $\begin{array}{l}\text { Time-period of time cycle. } \\
\text { Overall claims for repair and } \\
\text { warranty. } \\
\text { A number of repeat claims for } \\
\text { repair and warranty. } \\
\text { A number of repeat claims for } \\
\text { warranty satisfied at the first }\end{array}$ \\
\hline
\end{tabular}




\begin{tabular}{|c|c|c|}
\hline & notice within overall claims. & notice. \\
\hline $\begin{array}{c}\text { 4. Analysis of speed of } \\
\text { poor quality's goods } \\
\text { replacement (in case of } \\
\text { the delivery) }\end{array}$ & $\begin{array}{c}\text { Average time-period of poor } \\
\text { quality's goods replacement. }\end{array}$ & $\begin{array}{c}\text { Time-period of poor quality's } \\
\text { goods replacement. }\end{array}$ \\
\hline
\end{tabular}

The implications of the future applied strategic after-sales service analysis are as follows:

Detailed and specific ASASSA methodology development in terms of the indicators of separate stages and strategic after-sales service activity goals.

A development of the ASASSA techniques for individual companies in different industries.

The ASASSA extension onto the continuing operational activity indicators being a derivative of the BSC after-sales service score indicator.

A development of economic-mathematical models and computer programs enabling to apply the ASASSA for the after-sales service activity management.

\section{Conclusions}

Completing a consideration of the applied strategic after-sales service analysis a number of conclusions are drawn:

Applied strategic after-sales service analysis as a kind of the applied strategic analysis is a new and sufficiently effective instrument to research strategic aspects of the organization after-sales service activity forming analytical support for the strategic after-sales service management;

Its methodology constitutes concepts of the balanced scorecard and applied strategic analysis;

ASASSA presumes comparative assessment, variances diagnostics and forecast of the BSC after-sales service score indicators of the organization within its strategic goals of the after-sales service activity;

ASASSA comprises the analysis of the speed of billing, payment for the goods sold and arbitrations settlement; analysis of the due delivered goods updating; analysis of the speed of warranty and repair excellence; and analysis of the speed of poor quality's goods replacement (in case of the delivery);

ASASSA commences with the comparative assessment of the outcome indicators, characterizing the speed of billing, the payment for the goods sold and arbitrations settlement and is completed by the factoring indicators forecast of the poor quality's goods replacement (in case of the delivery);

Results of the ASASSA may be applied for the development and implementation decisions of the long-term, medium-term and short-term character in the field of the organization after-sales service activity.

\section{References}

1. Zhang, S., Dan, B., Zhou, M. (2019). After-sale service deployment and information sharing in a supply chain under demand uncertainty. European Journal of Operational Research, 279(2), 351-363.

2. Krylov, S. (2013). Applied strategic analysis as further balanced scorecard concept development, Proceedings of the $11^{\text {th }}$ Eurasia Business and Economics Society (EBES) conference (pp. 35-42). Ekaterinburg: Russian Acad. Sci., Inst. Econ., Ural Branch. 
3. Krylov, S. I. (2014). Theoretical aspects of economic balanced scorecard analysis. Asian Journal of Finance \& Accounting, 6(1), 90-109.

4. Kaplan, R. S., Norton, D. P. (1992). The balanced scorecard: Measures that drive performance. Harvard Business Review, 70(1), 71-79.

5. Kaplan, R.S. (2008). Conceptual foundations of the balanced scorecard. Handbook of Management Accounting Research, 3, 1253-1269.

6. Kaplan, R. S., Norton, D. P. (1993). Putting the balanced scorecard to work. Harvard Business Review, 71(5), 134-142.

7. Kaplan, R. S., Norton, D. P. (1996). The balanced scorecard: Translating strategy into action. Boston: Harvard Business School Press.

8. Kaplan, R. S., Norton, D. P., Rugelsjoen, B. (2010). Managing alliances with the balanced scorecard. Harvard Business Review, 88(1-2 SI), 114-120.

9. Doraszelski, U., Jaumandreu, J. (2013). R and D and productivity: Estimating endogenous productivity. Review of Economic Studies, 80(4), 1338-1383.

10. Lawrence, T. B. (1999). Institutional strategy. Journal of Management, 25(2), 161-187

11. Maisel, L. S. (1992). Performance management: The balanced scorecard approach. Journal of Cost Management, 6(2), 47-52.

12. Malholtra, N., Hinings, C. (2010). An organizational model for understanding internationalization processes. Journal of International Business Studies, 41(2), 330349.

13. Niven, P. R. (2014, A). Create a balanced scorecard of robust measures, meaningful targets, and strategic initiatives. Hoboken, NJ: John Wiley \& Sons Inc.

14. Niven, P. R. (2014, B). Integrating change management techniques to drive balanced scorecard success. Hoboken, NJ: John Wiley \& Sons Inc.

15. Niven, P. R. $(2014, \mathrm{C})$. Let everyone demonstrate their contribution by cascading the balanced scorecard. Hoboken, NJ: John Wiley \& Sons Inc.

16. Pearson, J. N., Feldman, H. D., Bracker, J. S. (1991). The impact of the product production process interaction of the evolution of the strategic response. Journal of Management Studies, 28(2), 161-172.

17. Van Biesebroeck, J. (2003). Productivity dynamics with technology choice: An applicftion to automobile assembly. Review of Economic Studies, 70(1), 167-198.

18. Kefe, I. (2019). The determination of performance measures by using a balanced scorecard framework. Foundations of Management, 11(1), 43-56.

19. Krylov, S., Ilysheva, N. (2016). Integrated management analysis of innovation performance in conditions of globalization. Proceedings of the $16^{\text {th }}$ International Scientific Conference on Globalization and Its Socio-Economic Consequences (pp. 734-740). Rajecke Teplice, Slovak Republic.

20. Krylov, S., Ilysheva, N. (2017). Strategic financial analysis based on balanced scorecard in present-day economic environment. Proceedings of The $17^{\text {th }}$ International Scientific Conference on Globalization and Its Socio-Economic Consequences (pp. 1194-1201). Rajecke Teplice, Slovak Republic.

21. Krylov, S. (2018). Strategic customer analysis based on balanced scorecard in presentday economic environment. Proceedings of the $18^{\text {th }}$ International Scientific Conference on Globalization and Its Socio-Economic Consequences (pp. 656-663). Rajecke Teplice, Slovak Republic. 
22. Krylov, S. (2020). Strategic operational analysis based on balanced scorecard in present-day economic environment. Proceedings of the $19^{\text {th }}$ International Scientific Conference on Globalization and Its Socio-Economic Consequences. Rajecke Teplice, Slovak Republic, OCT 09-10, 2019). SHS Web of Conferences, 74, 06016. 